\title{
Experimental Analysis Of Generic Antibiotics Along With Honey Sensitivity Against Microbial Flora Obtained From Frozen Hilsa Fish (Tenualosa ilisha)
}

\section{Sunandan Dey*}

Department of Pharmacy, University of Rajshahi, Rajshahi,

\begin{tabular}{|c|c|c|c|}
\hline Received: 06.05.2021 & Accepted: 22.06 .2021 & Published: 31.08 .2021 & - $\quad$ Final Version: 31.08.2021 \\
\hline
\end{tabular}

\begin{abstract}
This study deals with the in-vitro experimental analysis of different generic antibiotics and season based honey, sensitivity against isolated bacteria. The characterization of bacteria isolated from the frozen hilsa is done through various biochemical reactions The antibacterial sensitivity of honey and antibiotics are evaluated through zone of inhibition analysis of bacterial colony. So, it is obvious that this experiment provides providential values for future research including food value analysis.
\end{abstract}

Keywords: Tenualosa ilisha; Characterisation; Antibiotics; Honey; Sensitivity

\section{Introduction}

From the very past decade, the antibiotics are being used against bacterial disease. The antibiotics is one of the life saving drugs. If the all antibiotics are being resistant against bacterial, the bacterial infections will breakout. Then, life will be in a great threat.

Honey also has been used for a long time for its health benefits. Also, fish is a vital source of food for people and contributes about $60 \%$ of the world's supply of protein. Sixty percent $(60 \%)$ of the developing countries derived $30 \%$ of their annual protein from fish [1].

Protein is an important component of our food stuffs. Fish meats contains about 16-12\% protein [2]. It is also composed of water (66-81\%), carbohydrate (0.5\%), lipids (0.2-2.5\%), Ash(1.2-1.5\%) [3]. It also remains many minerals and vitamins in the fish meat. These are Calcium $(\mathrm{Ca})$, Iron( $\mathrm{Fe})$, Phosphorus (P), Magnesium (Mg), Manganese (Mn), Copper (Cu), Zinc ( $\mathrm{Zn})$, vitamin A, vitamin D, vitamin C. Hilsa (Tenualosa ilisha) is one of the well known fishes. The main ingredients of hilsa are vitamin A, vitamin C, omega-3 fatty acid, calcium $(\mathrm{Ca})$, phosphorus $(\mathrm{P})$, Zinc $(\mathrm{Zn})$, magnesium $(\mathrm{Mg})$. The component omega-3 fatty acid acts as a lipid lowering agent [4]. It is considered that one pound of hilsa meat contains average 3001100 calories energy. Hilsa is one of the most foreign exchange earing fishes. Hilsa is mainly found in revers and sea.The food ingredients (protein, carbohydrate, lipids) of frozen hilsa fish degrade for various invaded micro-organism including bacteria. These bacteria are susceptible for some antibiotics as well as resistant to some antibiotics. In this experimental study, the sensitivity of antibiotics against isolated bacteria is observed, which is perquisite for study of fish food. This in-vitro analysis, the generic antibiotics which is resistant to isolated bacteria, provides intuitive information regarding the antibiotics used for bacterial

\footnotetext{
* Corresponding Author: sunandandeypharmacy@gmail.com
} 
infectious diseases. In addition, the antibacterial properties of honey is obliviously a providential evidence for future research in this perspective.

\section{Materials and Methods}

\subsection{Sample collection}

For the current research works, the 5-6 months frozen hilsa was collected from the local market and samples were obtained from different body parts including dermis, kidney, liver, gill, and intestine. The bacteria were isolated from the body parts (dermis, kidney, liver, gill, intestine) of the sample frozen hilsa with sterilized scalpel and from it a small portion was took in LB(Luria-Bertani broth) liquid medium and mixed bacterial cultures were grown.

\subsection{Colony characteristics, Gram reaction and Cell morphology}

The isolates were inoculated both on solid and liquid LB medium. Colony characteristics of the isolates on LB medium were noted after $24 \mathrm{hrs}$ incubation at $28^{\circ} \mathrm{C}$. Gram's staining [5](differentiation of Gram-positive and Gram-negative bacteria), Oxidase test [6](cytochrome c oxidase, an enzyme of the bacterial electron transport chain) test, Catalase [7](an enzyme present in most of the organisms and is involved in decomposition of the hydrogen peroxide in $\mathrm{H}_{2} \mathrm{O}$ and $\mathrm{O}_{2}$ ) test, Sulfide-indole motility (SIM) test [8](differentiation of bacteria based on three tests: sulfur reduction (cysteine desulfurase), indole production (tryptophanase), and motility, Simmons citrate test [9], MacConkey agar test [10](differentiation of lactose fermenting from lactose nonfermenting Gram-negative bacteria), Kligler Iron agar (KIA) [11](used in differentiating certain members of the Enterobacteriaceae by demonstrating hydrogen sulfide production and the fermentation of dextrose and lactose), Urease [12](an enzyme that hydrolyze urea providing a source of nitrogen for bacteria), Antibiotic sensitivity test [13](in vitro employing standard disc diffusion method), if inhibition zone was 5-10 mm it was considered as resistant (R), 11-15 mm inhibition zone was considered as intermediate (I), and $\geq 16 \mathrm{~mm}$ was considered as sensitive (S).

Table 1. Antibiotic discs of different concentration used in the experiment

\begin{tabular}{ll}
\hline Antibiotic discs & Disc concentration \\
\hline Oxytetracycline & $30 \mu \mathrm{g}$ \\
Cefixime & $5 \mu \mathrm{g}$ \\
Cefotaxime & $30 \mu \mathrm{g}$ \\
Nalidixic Acid & $30 \mu \mathrm{g}$ \\
Kanamycin & $30 \mu \mathrm{g}$ \\
Vancomycin & $30 \mu \mathrm{g}$ \\
Doxycycline & $30 \mu \mathrm{g}$ \\
Neomycin & $30 \mu \mathrm{g}$ \\
Gentamycin & $10 \mu \mathrm{g}$ \\
\hline
\end{tabular}




\begin{tabular}{lc} 
Erythromycin & $15 \mu \mathrm{g}$ \\
Sulfonamide & $300 \mathrm{IU}$ \\
Amoxicillin & $30 \mu \mathrm{g}$ \\
Penicillin-G & $10 \mu \mathrm{g}$ \\
Rifampicin & $5 \mu \mathrm{g}$ \\
\hline
\end{tabular}

\subsection{Antibacterial effect of honey on isolated bacterial strain}

For evaluation of antibacterial efficacy of honey, we used different concentration of honey $(10,20$ and $30 \mu 1$ ). In our study we used 3 types of honey (Summer, Winter, Spring) and every type of honey consist of 3 concentration $(10,20$ and $30 \mu \mathrm{l})$.After that we measured zone of every of honey.

Table 2. of nutrient broth

\begin{tabular}{ll}
\hline Constituents & Amount $(\mathrm{g} / \mathrm{L})$ \\
\hline Peptone & 10 \\
Yeast extract & 5 \\
$\mathrm{NaCl}$ & 5 \\
\hline
\end{tabular}

Table 3. of nutrient agar

\begin{tabular}{ll}
\hline Constituent & Amount $(\mathrm{g} / \mathrm{L})$ \\
\hline Peptone & 10 \\
Yeast extract & 5 \\
$\mathrm{NaCl}$ & 5 \\
Agar & 20 \\
\hline
\end{tabular}

\section{Observation and Results}

\subsection{Morphological and Biochemical Characterization of Isolate Bacterial Strains:}

Various biochemical tests were carried out to characterize the isolated bacteria. The results of the biochemical tests are summarized in table 4 .

Table 4. results of morphological and biochemical test

\begin{tabular}{llllll}
\hline \multirow{2}{*}{ Name of tests } & \multicolumn{2}{l}{ Results } & & & \\
\cline { 2 - 6 } & A & B & C & D & M \\
\hline Gram Staining & - & - & - & - & + \\
Oxidase & + & + & + & - & + \\
Catalase & + & - & - & + & + \\
\hline
\end{tabular}




\begin{tabular}{llllll}
$\begin{array}{l}\text { Sulfide } \\
\text { Indole } \\
\text { Motility }\end{array}$ & + & + & + & + & - \\
\hline $\begin{array}{l}\text { Simmon citrate utilization } \\
\text { Growth on MacConkey }\end{array}$ & + & + & + & + & - \\
$\begin{array}{l}\text { agar } \\
\text { Kligler iron agar }\end{array}$ & + & + & + & + & - \\
Urease & + & + & + & + & - \\
\hline
\end{tabular}

\section{Gram Staining Test.}

Maintaining the suitable staining method, the following result was observed for isolated bacterial strain (Tab.5). Isolate $\mathrm{M}$ bacterial strains showed purple color indicating gram-positive rod-shaped bacteria but isolate $\mathrm{G}, \mathrm{D}, \mathrm{Kw}, \mathrm{Kc}$ show pink color indicating gram negative. Here, $\mathrm{G}=\mathrm{Gill}, \mathrm{D}=$ Dermis, $\mathrm{M}=$ Muscle, $\mathrm{Kw}=$ Kidney White and $\mathrm{Kc}=$ Kidney creamy.
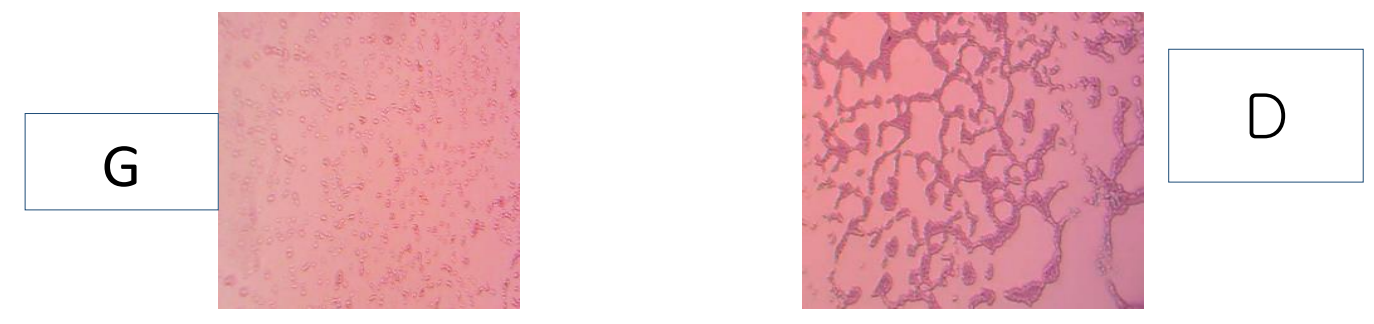

Figure 1. Gram Staining test of bacteria

\section{Antibacterial activity of antibiotics against isolated bacteria:.}

In this observation, disk diffusion method was used to test antibacterial sensitivity of the five isolated bacteria. After incubation period the diameter of the inhibition zone was scrutinized.
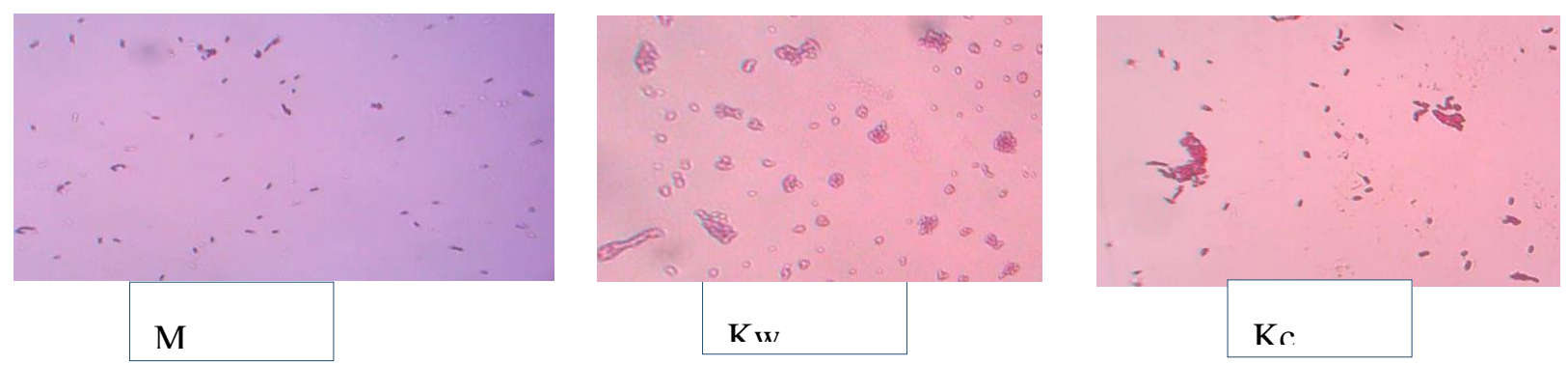

Figure 2. staining result of isolated bacterial strains.

Table 5. sensitivity test used for the detection of the resistance pattern of the isolated bacteria.

\begin{tabular}{llllllll}
\hline \multirow{2}{*}{ Antibiotic discs } & $\begin{array}{l}\text { Disc } \\
\text { concentration }\end{array}$ & \multicolumn{4}{l}{$\begin{array}{l}\text { Zone of inhibition (mm) } \\
\text { (Sensitivity) }\end{array}$} \\
\cline { 3 - 7 } & $\mathrm{A}$ & $\mathrm{B}$ & $\mathrm{C}$ & $\mathrm{D}$ & $\mathrm{E}$ \\
\hline Oxytetracycline & $30 \mu \mathrm{g}$ & $11(\mathrm{I})$ & $10(\mathrm{R})$ & $15(\mathrm{I})$ & $14(\mathrm{I})$ & $30(\mathrm{~S})$ \\
\hline
\end{tabular}




\begin{tabular}{lllllll}
\hline Cefixime & $5 \mu \mathrm{g}$ & $12(\mathrm{I})$ & $10(\mathrm{R})$ & $12(\mathrm{I})$ & $19(\mathrm{~S})$ & $10(\mathrm{R})$ \\
Cefotaxime & $30 \mu \mathrm{g}$ & $14(\mathrm{I})$ & $13(\mathrm{I})$ & $12(\mathrm{I})$ & $20(\mathrm{~S})$ & $12(\mathrm{I})$ \\
Nalidixic Acid & $30 \mu \mathrm{g}$ & - & - & $8(\mathrm{R})$ & $10(\mathrm{R})$ & $24(\mathrm{~S})$ \\
Vancomycin & $30 \mu \mathrm{g}$ & - & - & $7(\mathrm{R})$ & - & $22(\mathrm{~S})$ \\
Doxycycline & $30 \mu \mathrm{g}$ & $10(\mathrm{R})$ & $9(\mathrm{R})$ & $8(\mathrm{R})$ & $10(\mathrm{R})$ & $30(\mathrm{~S})$ \\
Neomycin & $30 \mu \mathrm{g}$ & $12(\mathrm{I})$ & $11(\mathrm{I})$ & $13(\mathrm{I})$ & $10(\mathrm{R})$ & $22(\mathrm{~S})$ \\
Gentamycin & $10 \mu \mathrm{g}$ & $14(\mathrm{I})$ & $18(\mathrm{~S})$ & $17(\mathrm{~S})$ & $19(\mathrm{~S})$ & $25(\mathrm{~S})$ \\
Erythromycin & $15 \mu \mathrm{g}$ & - & - & $20(\mathrm{~S})$ & - & $20(\mathrm{~S})$ \\
Sulfonamide & $300 \mathrm{IU}$ & $10(\mathrm{R})$ & $15(\mathrm{I})$ & $15(\mathrm{I})$ & $10(\mathrm{R})$ & $10(\mathrm{R})$ \\
Amoxicillin & $30 \mu \mathrm{g}$ & - & - & - & - & $10(\mathrm{R})$ \\
Penicillin-G & $10 \mu \mathrm{g}$ & - & - & $10(\mathrm{R})$ & $10(\mathrm{R})$ & $23(\mathrm{~S})$ \\
Rifampicin & $5 \mu \mathrm{g}$ & - & - & $8(\mathrm{R})$ & $9(\mathrm{R})$ & $20(\mathrm{~S})$ \\
Azithromycin & $15 \mu \mathrm{g}$ & $15(\mathrm{I})$ & $18(\mathrm{~S})$ & $13(\mathrm{I})$ & $11(\mathrm{I})$ & $13(\mathrm{I})$ \\
\hline
\end{tabular}

Note: Resistant $=<10 \mathrm{~mm}$; Intermediate $=10-15 \mathrm{~mm}$; Susceptible $=>15 \mathrm{~mm}$

\section{Antibacterial activity of honey sample.}

In this study, honey disk was used to test antibacterial sensitivity of the five isolated bacteria. The patterns of sensitivity and resistance of isolated bacterial cultures honey was tested by the disk diffusion method using nutrient agar medium. After overnight incubation at $37^{\circ} \mathrm{C}$ the diameter of the inhibition zone was measured.

Table 6. sensitivity against bacteria.

\begin{tabular}{|c|c|c|c|c|c|c|c|}
\hline \multirow{2}{*}{ Isolate } & \multirow{2}{*}{$\begin{array}{l}\text { Concentration } \\
(\mu 1)\end{array}$} & \multicolumn{6}{|c|}{ Honey (Zone of Inhibition at mm) } \\
\hline & & Summer & Response & Winter & Response & Spring & Response \\
\hline \multirow{2}{*}{$\mathbf{A}$} & $10 \mu 1$ & $8 \mathrm{~mm}$ & Resistant & $6 \mathrm{~mm}$ & Resistant & $8 \mathrm{~mm}$ & Resistant \\
\hline & $20 \mu 1$ & $10 \mathrm{~mm}$ & Resistant & $9 \mathrm{~mm}$ & Resistant & $10 \mathrm{~mm}$ & Resistant \\
\hline \multirow{4}{*}{ B } & $30 \mu 1$ & $14 \mathrm{~mm}$ & Intermediate & $12 \mathrm{~mm}$ & Intermediate & $12 \mathrm{~mm}$ & Intermediate \\
\hline & $10 \mu 1$ & $15 \mathrm{~mm}$ & Intermediate & $12 \mathrm{~mm}$ & Intermediate & $6 \mathrm{~mm}$ & Resistant \\
\hline & $20 \mu 1$ & $18 \mathrm{~mm}$ & Sensitive & $17 \mathrm{~mm}$ & Sensitive & $6 \mathrm{~mm}$ & Resistant \\
\hline & $30 \mu 1$ & $22 \mathrm{~mm}$ & Sensitive & $18 \mathrm{~mm}$ & Sensitive & $8 \mathrm{~mm}$ & Resistant \\
\hline \multirow{2}{*}{$\mathbf{C}$} & $10 \mu \mathrm{l}$ & $6 \mathrm{~mm}$ & Resistant & $10 \mathrm{~mm}$ & Resistant & $8 \mathrm{~mm}$ & Resistant \\
\hline & $20 \mu 1$ & $10 \mathrm{~mm}$ & Resistant & $22 \mathrm{~mm}$ & Sensitive & $10 \mathrm{~mm}$ & Resistant \\
\hline \multirow{4}{*}{ D } & $30 \mu 1$ & $12 \mathrm{~mm}$ & Intermediate & $23 \mathrm{~mm}$ & Sensitive & $14 \mathrm{~mm}$ & Intermediate \\
\hline & $10 \mu 1$ & $08 \mathrm{~mm}$ & Resistant & $08 \mathrm{~mm}$ & Resistant & $8 \mathrm{~mm}$ & Resistant \\
\hline & $20 \mu 1$ & $10 \mathrm{~mm}$ & Resistant & $12 \mathrm{~mm}$ & Intermediate & $10 \mathrm{~mm}$ & Resistant \\
\hline & $30 \mu 1$ & $10 \mathrm{~mm}$ & Resistant & $15 \mathrm{~mm}$ & Intermediate & $10 \mathrm{~mm}$ & Resistant \\
\hline
\end{tabular}




\begin{tabular}{|c|c|c|c|c|c|c|c|}
\hline $\mathbf{E}$ & $10 \mu \mathrm{l}$ & $20 \mathrm{~mm}$ & Sensitive & $24 \mathrm{~mm}$ & Sensitive & $20 \mathrm{~mm}$ & Sensitive \\
\hline & $20 \mu \mathrm{l}$ & $25 \mathrm{~mm}$ & Sensitive & $25 \mathrm{~mm}$ & Sensitive & $24 \mathrm{~mm}$ & Sensitive \\
\hline & $30 \mu \mathrm{l}$ & $29 \mathrm{~mm}$ & Sensitive & $27 \mathrm{~mm}$ & Sensitive & $28 \mathrm{~mm}$ & Sensitive \\
\hline
\end{tabular}

\section{Discussion}

The present studies were carried out to identify and characterize bacteria isolated from frozen hilsa (Tenualosa ilisha). It was found that among the five isolated bacteria (isolate $-\mathrm{D}, \mathrm{G}, \mathrm{Kc}, \mathrm{Kw}$, and $\mathrm{M})$; isolate- $\mathrm{D}, \mathrm{G}, \mathrm{Kc}, \mathrm{Kw}$ were gram-negative and isolate - $\mathrm{M}$ was gram-positive. Colonies of the first four isolates were fairly round shaped and later one was irregular in shape. Biochemical tests indicate that isolates G, D, Kc and Kw were catalase, KIA, SIM test, MacConkey agar test Urease test positive.Other one isolates $\mathrm{M}$ showed negative result for all these biochemical tests. All the five isolates were positive to catalase test. In SIM test all the isolates showed negative result for Hydrogen Sulphide and Indole. In case of isolates G, D, Kc, Kw, simmon citrate, urease was positive.

In antibiotic test, the result showed that all of the five isolate were susceptible to Oxytetracycline, Cefotaxime and cefixime while they were resistant to Penicillin-G and Rifampicin. However, the results revealed that the different antibiotics as well. Where isolate $\mathrm{D}, \mathrm{G}, \mathrm{Kc}, \mathrm{Kw}$ exhibited highest sensitivity to Cefotaxime, Cefixime and Erythromycine and $\mathrm{M}$ showed highest sensitivity to Oxytetracyline and Doxycycline. In this study, the highest inhibition was $30.0 \mathrm{~mm}$ for isolate $\mathrm{M}$ created by Oxytetracyline. The lowest $8.0 \mathrm{~mm}$ zone was found by Rifampicin. In a study it was reported that Oxytetracycline showed highest $30.0 \mathrm{~mm}$ diameter of zone of inhibition against isolated bacteria.

In antibacterial test, the use of honey as a traditional remedy for microbial infections dates back to ancient times. The difference in antibacterial potency among the different honeys can be more than 100-fold, depending on its geographical, seasonal and botanical source as well as through harvesting,processing and storage condition. The antibacterial activity of honey is attributed largely to osmolarity, hydrogen peroxide production. Honey contains glucose and glucose oxidase to produce hydrogen peroxide.

In this study, the honey of summer, winter, and spring were collected from a local trader and used for experiment to which amount was 10, 20, $30 \mu \mathrm{l}$ respectively. In the in vitro experimental methods, it was used agar diffusion disc method to where honey was used as an antimicrobial agent to observe the zone of inhibition of bacterial growth. The highest zone of inhibition of summer, winter, spring season collected honey was $20 \mathrm{~mm}, 18 \mathrm{~mm}, 22 \mathrm{~mm} ; 24 \mathrm{~mm}, 25 \mathrm{~mm}, 18 \mathrm{~mm} ; 20 \mathrm{~mm}, 24 \mathrm{~mm}, 8 \mathrm{~mm}$

\section{Conclusion}

Most of the isolated bacteria show positive results for most biochemical tests, reveals the negative strain of the isolates. Antibiotic sensitivity test shows highest inhibition for Muscle with Oxytetracycline and Doxycycline. Where Kideny white shows highest inhibition with Cefixime and Cefotaxime. Gill and Kideny Creamy show highest inhibition with Gentamycin, whereas Dermis does not show any susceptible results at all. Antibacterial activity test in case of honey Muscle showed highest inhibition during summer and winter. Where Kideny Creamy shows higher inhibition during winter. 


\section{Acknowledgements}

The author would like to acknowledge the Rajshahi University, Rajshahi-6205, Bangladesh for providing lab facilities.

\section{Data Availability Statement}

No data availablity statement.

\section{References}

[1] Murray J, Burt J.R. (2001) The Composition of Fish. Torry Advisory Note No. 38, Ministry of Technology. Torry Research Station, UK p: 14

[2] Pillay S.R, Rosa H.J. (1963) Synopsis on the biological data on hilsa, Hilsailisha (Hamilton, 1822). FAO Fisheries Biology Synopsis p: 65.

[3] FAO (1999) World production of fish, crustaceans and mollusks by major fishing areas. Fisheries Information Data and Statistics Unit (FIDI), Fisheries Department, FAO, Rome, Italy.

[4] Skulas-Ray, A. C., Wilson, P. W., Harris, W. S., Brinton, E. A., Kris-Etherton, P. M., Richter, C. K., ... \& Welty, F. K. (2019). Omega-3 fatty acids for the management of hypertriglyceridemia: a science advisory from the American Heart Association. Circulation, 140(12), e673-e691.

[5] Hucker, G. J., \& Conn, H. J. (1923). Methods of Gram staining.

[6] Shields, P., \& Cathcart, L. (2010) Oxidase test protocol. American Society for Microbiology.

[7] Karen R. (2010) Catalase test protocol, ASM MicrobeLibrary,.

[8] MacWilliams, M. (2009). Citrate Test Protocol. American Society for Microbiology.

[9] Mossel, D. A. A., Mengerink, W. H. J., \& Scholts, H. H. (1962). Use of a modified MacConkey agar medium for the selective growth and enumeration of Enterobacteriaceae. Journal of Bacteriology, 84(2), 381-381.

[10] Johnson, J. G., Kunz, L. J., Barron, W., \& Ewing, W. H. (1966). Biochemical differentiation of the Enterobacteriaceae with the aid of lysine-iron-agar. Applied microbiology, 14(2), 212-217.

[11] Benita B. (2010) Urease test protocol, Washington, DC: American Society for Microbiology,.

[12] Dickert, H., Machka, K., \& Braveny, I. (1981). The uses and limitations of disc diffusion in the antibiotic sensitivity testing of bacteria. Infection, 9(1), 18-24. 